\title{
Traumatic Redemption Chronotope as Theoretical Model to Study Serial Shakespeares
}

Víctor Huertas Martín

Universidad de

Extremadura 


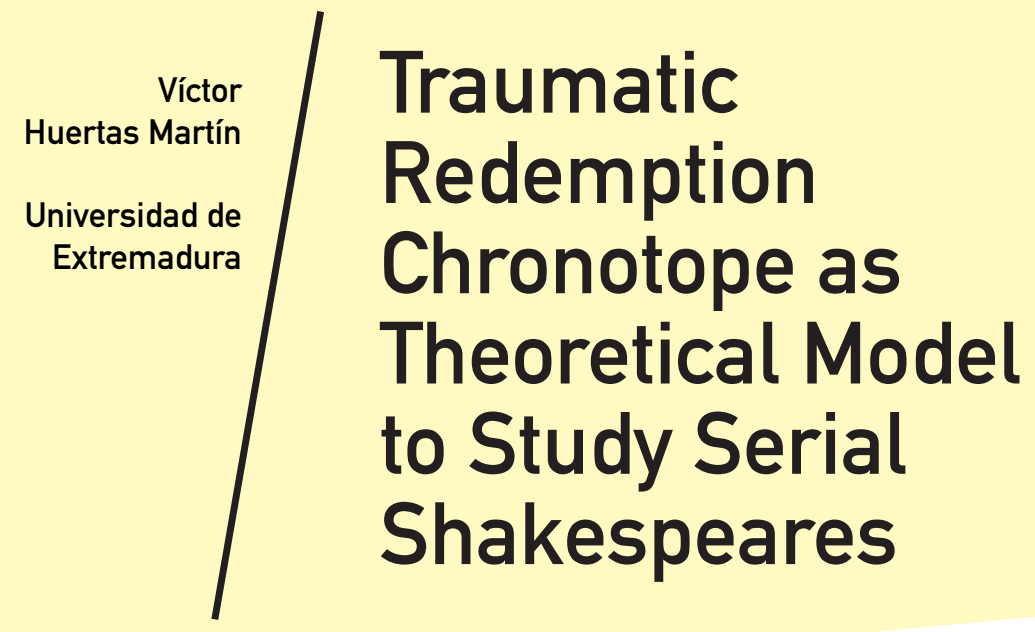

his article proposes a methodology to study Shakespearean intertexts in contemporary complex TV series. While the presence of Shakespeare's inter-texts in contemporary complex TV seems ubiquitous, a sustained and theoretically focused academic study of the impact of Shakespeare in these works has not been produced. Reviewers and social media users' comments have proposed readings of the series pointing at the importance of the series' redemptive qualities. Taking Hannah Wolfe Eisner's "Into the Middle of Things: Traumatic Redemption and the Politics of Form" as basis, I am presenting a theoretical model to study serial Shakespeares, with which I am referring to a limited corpus of American complex TV series appropriating Shakespeare's texts, as narratives embedded in a cultural politics of trauma and redemption. Additionally, it shows that such series potentially work as guidelines to study the overall impact of traumatic redemption in other contemporary adaptations of Shakespearean plays.

Key Words: Shakespeare, Inter-text, Appropriation, Trauma, Redemption 
There is consensus that Shakespeare's adapted texts end up being both Shakespeare's and someone else's. Thus, oftentimes Shakespearean adaptations and appropriations are studied alongside conventions of film genres, fictional styles or the narrative procedures of new media, such as web series or vlogs, etc. Yet, the overall impact of Shakespeare's intertexts in complex TV series has been examined only in part. This article reviews criticism situating the Shakespearean intertexts in complex series in a light that makes them analyzable from the lens of traumatic redemption. It sets down the theoretical premises for such a study and provides examples on how it may develop.

Doubtless, complex TV series have followed the $21^{\text {st }}$ century trend to appropriate Shakespearean materials to supply other narratives which rework such texts according to their conventions. Thus, they appropriate Shakespearean narrative structures, themes, characters, textual references, etc. to enrich their own narratives. This has not escaped teachers, bloggers, journalists and artists who make it a point to identify their Shakespearean readings with HBO, Netflix or Fox. As Kinga Földváry suggests, "it is instructive to see what purposes Shakespeare and his characters are made to serve on contemporary American television" (6). Such purposes are necessarily constrained by media features and conventions of genres. In this case, Jason Mittel's description of the features of complex TV -a form of storytelling occluding "the need for plot closure within every episode that typifies conventional episodic form," that foregrounds "ongoing stories across a range of genres" and deploys "a range of serial techniques" (18)- supplies an overall syntax for series. Thematically, many series engage in dialectics of trauma and redemption. The lack of redemptive closure and the conflicting narrative strands in series -which delay resolution for years- are enmeshed with Shakespearean inter-texts deployed through them.

Culturally speaking, series have constituted a prestige culture which, as the story goes, leaves behind formulaic $20^{\text {th }}$ century television in lieu of ground-breaking creativity and artistic quality ${ }^{1}$. Such statements have met criticism. Concepción Cascajosa-Virino critiques the neoliberal policies of private channels and distributors who, disguised as promoters of élite culture, vest their interests on the placement of new technologies and apparatuses. Cascajosa-Virino also exposes contemporary series' perpetuating of gender and race inequalities that are a far cry from the progressive promise they make. A look at the corpus of series confirms that these white male-centered cultural hierarchies remain fundamentally unchallenged. However, these cultural hierarchies lay the foundations for narratives energizing a trauma-redemption dialectics by exposing these problematic characters' zig-zagging journeys.

Shakespeare's prestige as an icon of world literature, like the prestige of series, does not work outside ideology. Critics such as Michael D. Bristol and Susan Bennett have observed that Shakespeare's cultural capital has been used to perpetuate economic inequalities via distribution and dissemination of prestige culture. Yet, Bristol himself and others, such as Denise Albanese), admit that audiences have been able to find genuine value in their experiencing of Shakespeare

\footnotetext{
${ }^{1}$ As Christopher Anderson puts it,"In the case of HBO dramas, the aesthetic disposition brings to television the cultivated expectation that watching certain television series requires and rewards the temperament, knowledge, and protocols normally considered appropriate for encounters with museum-worthy works of art” (24).
} 
Complex TV series' constant associations with Shakespeare present the same ambivalent picture. Starting with George Anastasia's statement, "If Shakespeare were alive today. he'd be writing for The Sopranos". a plethora of catchy phrases arouses the suspicion that Shakespeare's cultural capital is being used just to indicate that the product is high quality. 
even in ideologizing contexts. Complex TV series' constant associations with Shakespeare present the same ambivalent picture. Starting with George Anastasia's statement, "If Shakespeare were alive today, he'd be writing for The Sopranos", a plethora of catchy phrases arouses the suspicion that Shakespeare's cultural capital is being used just to indicate that the product is high quality. Nonetheless, I suggest that we take such contributions seriously, for they, as I will show, offer powerful insights to understand Shakespeare's relation to series.

This research owes, in fact, much to such contributions. TV serials such as Rome, Deadwood, Empire, Succession, Sons of Anarchy, Boardwalk Empire, Game of Thrones, House of Cards or Westworld insert Shakespearean quotations, references and allusions and use Shakespearean themes and narratives to reinforce stories of traumatic redemption. Trauma culture, as recent critical writings show, gained resurgence after the disaster of 9/11 in the US and, arguably, it spread across continents ${ }^{2}$. Cultural memory, collective and individual suffering and pain as well as different forms of redemption and emancipation are of interest in the narrativization of trauma and the search for affirmative outcomes to the suffering that trauma provokes. A crucial question to answer is whether Shakespearean texts strengthen the healing of the pain or provide forward gazes out of the traumatic experience. Since the question of how we heal is as crucial as the goal of healing, we think that Hannah Wolfe Eisner's model provides an adequate lens to think of Shakespeare's contribution to redemption in dialectic, not absolute, terms.

\section{CRITICAL REVIEW}

In her analysis of Deadwood made through the lens of Shakespeare's Henry IV, Susan C. Ronnenberg identifies a "response to $9 / 11$, seeking removal from the present given horrific national trauma, but choosing an historic setting that would permit exploration of some aspects of national anxiety regarding American values and identity related to that event" (25). Such trauma she associates to both works, for, as Ronnenberg later argues, characters in them are "predicated on their pasts, forcing them to return to their own personal histories in an attempt to negotiate their problems in the present" (26).

Other essays engage with serials as appropriations of Shakespeare's plays, often setting the foundations for further exploration through the lens of trauma-redemption dialectics. In her analyses of Rome, Sylvaine Bataille departs from the premise that Bruno Heller and the creators resisted Shakespeare's legacy. Yet, as Bataille suggests, the ghost of Shakespeare often appears (2008). In a later essay, she shows the strategies followed by Rome's creators to dialectically engage with Shakespeare through the series' negative portrayal of the ruling classes, using offensive unShakespearean language and graphic sex and violence to clear the story from the dust of bookish

1 See Kaplan, E. A. Trauma Culture (The Politics of Terror and Loss in Media and Literature). New Brunswick, New Jersey, London: Rutgers University Press, 2005. Print.

On Shakespeare and the culture of trauma, see Silverstone, C. Shakespeare, Trauma and Contemporary Performance. New York; London: Routledge, 2011. Print.; Hawkes, T., M. Biberman \& J. Lupton. Shakespeare After 9/11 (How Trauma Reshapes Interpretation). New York; Queenston: The Edwin Mellen Press, 2011. Print. 
graveness (2009).I suggest that Bataille's presupposed audience knowledge of Shakespeare's Julius Caesar -expressed, for instance, via self-conscious omissions of some well-known passages (e.g.'E tu Brute') (2009)- be further explored. Also, Bataille hits on the nail when she points at the series' emphasis in both essays on the role played by the People of Rome in the narrative. Such a role which has produced a massive corpus of speculation in Shakespearean criticism and which, largely, remains undefined by Shakespeare. Thus, Rome aligns Shakespearean intertexts with a set of conventions identified by Russell Jackson's description of Holly Rome's metanarrative: the struggle of the People of Rome to be free. Rome combines the audience's knowledge of Shakespeare -a play culturally, ideologically and politically relevant for the configuration of the US state- and a shared culture based on US Roman narratives, which have traditionally linked Christianity to freedom and a democratic ethos (2008).

\section{Trauma culture, as recent critical writings show, gained resurgence after the disaster of 9/11 in the US and, arguably. it spread across continents.}

Analyzing Sons of Anarchy (SOA), Katarzyna Burzynska (2017) pairs Shakespeare's and Sutter's works as models for patriarchal familial ideologies, upon whose structures lies stability in both fictional worlds. Doubtless, such an essay studying the cultural transposition of the patriarchal hierarchies in Hamlet to the contemporary context of SOA helps rethinking the series' problematizing of these structures. Bataille (2008) identifies Jax's hesitation on the course of action to take and his changes of heart as fundamental to his construction as a modern Hamlet. However, the imperative guidelines of complex TV, as Bataille suggests, force the hero to be proactive, a fact which has been problematic to develop this idea properly. To tackle these, as she continues, Sutter deployed a repertoire of narrative strategies dilluding the literary classic, transforming it into a narrative memory for another age and, for that purpose, elements of Hamlet are appropriated (2008). Thus, Jax Teller's journey involves exploration of the sources of his anxieties as well as his 
desires to provide his family with a better future. Nonetheless, such exploration goes alongside the hero's apparent inability to escape his outlaw fate.

Many contributions by bloggers and social media users engage in the complex interpretive activity of using Shakespeare's play to predict the series' outcomes, which often leads to imaginative and convincing predictions. But, most important, some attention has been paid to the redemptive features of the series. As Sutter indicates in interviews, "This [season seven] is the season coming up where Jax needs to decide. There is no more debate.I think it's the season where he's in or out [of the club]" (Ford n. p.). Not all interpretations in these sense associate Teller with Hamlet but rather with a Christ-like sacrifice figure. Joanna Robinson eschews debates on obvious Shakespearean references and stresses this aspect of Jax's characterization:

Sons of Anarchy was so enamoured with the idea of Jax as Jesus that they packed the [final] episode to the gills with references to his martyrdom. Any one of these Jesus references might have been a nice touch, but the frenzy of imagery just made Jax's end ridiculous, rather than tragic. (Robinson n. p.)

\section{Many contributions by bloggers and social media users engage in the complex interpretive activity of using Shakespeare's play to predict the series' outcomes, which often leads to imaginative and convincing predictions.}

Robinson refers to Jax's suicide riding his bike, opening his arms wide right before clashing with a track in the middle of the road. The last shot reveals Jax's blood and a piece of bread getting stained with it. Robinson's critique on this labored ending points precisely at what makes Jax's redemption story relevant, for Sutter self-consciously heightens this excess of Christian associations in ways that incite skeptic readings on the meaningfulness of Jax's sacrifice. Troy L. Smith reads SOA as a story which is "also about love, loyalty and people trying (and failing) to find the right way to do the wrong things. Just like 'The Walking Dead' is about humankind being its own worst enemy, 'Sons of Anarchy' is about reconciling who you are with learning to live with it" (n. p.). In a post-industrial context in which the US working-classes need to find their way out of under-education, Smith's analogy of mankind turning against itself while trying to survive gains weight and significance in the political and ideological worlds depicted in these series.

Amidst a plethora of GOT reviews which mostly deploy character parallels and interpretations of Martin's quotes as Shakespearean paraphrases, it is significant that the serials' motto -the motto of the House Stark- ("Winter is coming") bears resemblance to the opening sentence in Shakespeare's Richard III ("Now is the winter of our discontent"). R. R. Martin identifies 


\section{In a post-industrial context in} which the US working-classes need to find their way out of under-education, Smith's analogy of mankind turning against itself while trying

to survive gains weight and significance in the political and ideological worlds depicted in these series. 


\section{The geopolitical context of}

the series, immerse in global conflict, terrorism, a lack of faith

in the institutions - particularly

the Presidency of the US and, importantly, the risk of socioeconomic exclusion affecting

the US and the world's working classes should, in principle, make us think of complex TV works as politically concerned and progressive in their criticism of leading institutions, surveillance, financial capitalism and sustained irresponsible economic growth reliant on predatory practices such as gentrification and the state's involvement in public scandals. 
winter with a "deeper metaphorical meaning generally expressing the sentiment that dark periods occur in life. Even if things are currently going well in your world ("summer"), this won't last forever. There will eventually come a dark period, a coldness, when events turn against us ("winter") [...] nobody is ever safe or comfortable for too long" (Saporito n. p.). Yet, such a winter, arguably, precedes a change and redemption or new beginning marking a recovery of faith and hope. At least, this goes for some of the identifications established between GOT and Shakespeare. As Matt Amarall, whose associations between GOT and Shakespeare include passages from Othello or Antony and Cleopatra, says, "In their characters [Martin's and Shakespeare's] we see ourselves, in their struggles we see our own, and in the unjust world in which they live we still see hope... If you want to know how it all ends [in Martin's work and HBO's series], you might want to revisit the old Bard, because I can tell you -there are hints everywhere" (n. p.). Indeed, the clues for such hopeful readings may indeed lie in the series' possible associations with Shakespearean romances. Also, these expectations may explain why many fans were disappointed with the ending of GOT.As Slavoj Žižek says:

The stakes in the final conflict are thus: should the revolt against tyranny be just a fight for the return of the old kinder version of the same hierarchical order, or should it develop into the search for a new order that is needed? The finale combines the rejection of a radical change with an old anti-feminist motif.(2019: n. p.)

\section{Literature, enlightenment and emancipation forces in Westworld wave Shakespearean flags.}

Westworld (Lisa Joy and Jonathan Nolan, 2016-), based on the film written and directed by Michael Crichton in 1973, has attracted public attention using Shakespearean quotations and the uncanny reworking of neo-baroque meta-theatricality as an oppressive metaphor.Yet, it is possible to think of emancipatory readings too. Fans have contributed to develop insightful interpretations of the quotes across the episodes of the first series. Peter Abernathy, a host programmed to have been a teacher and an ex-member of a theatre company, combines two fractured quotes from Shakespeare:'By my most mechanical and dirty hand' (Henry IV Part 1) and 'I shall have revenges on you both' (King Lear). Many commentators have pointed at the redemptive potentialities underlying sustained reading of the quotes, though some voices, such as Daniel Pollack-Pelzner's, disclaim such potentialities. 
For Pollack-Pelzner, Shakespeare served capitalist ideological purposes for those taking part in the Westward movement who carried copies of Shakespeare's works with them. This may be so, but some narratives propose alternative readings. Helen Wickham Koon's study, How Shakespeare Won the West (Players and Performances in America's Gold Rush, 1849-1865), shows how miners and workmen travelling westward attended Shakespearean performances as "enlightenment to the spirit” (1989: 4). This idea may be equally applied to Westworld.As David Rodemerk suggests, when combining the quotes in Westworld, the effect is that the mechanicals, figures generally scorned in Shakespeare's text, now are ready to lead a rebellion. As Noel Ceballos affirms, Abernathy, in his remembering of his acting days, fathoms an emancipatory force which comes associated with his memories of Shakespeare in the theatre. As Janey Tracey says, in Shakespeare's King Lear, Lear earns an 'enlightened soul' through suffering. In this way, "the androids may achieve enlightenme The Wire nt through their traumatic reveries - and through their exposure to literature" Furthermore, as Matt Patches suggests,, the series' delving in trauma is not a cynical study but a recognition that "Grief, and the little voice in [the human] head who wrestles with those though situation, is what makes us human" (n. p.). Katheleen Walsh's explanation of the show's quotes of Romeo and Juliet suggests another emancipatory movement lying ahead once the hosts - symbolizing the alienated underdogs of mankind in the era of neoliberalism - violently revolt against those who oppress them. Literature, enlightenment and emancipation forces in Westworld wave Shakespearean flags.

\section{THEORETICAL MODEL: CHRONOTOPE OF TRAUMATIC REDEMPTION FOR SERIAL SHAKESPEARES}

The geopolitical context of the series, immerse in global conflict, terrorism, a lack of faith in the institutions - particularly the Presidency of the US - and, importantly, the risk of socioeconomic exclusion affecting the US and the world's working classes should, in principle, make us think of complex TV works as politically concerned and progressive in their criticism of leading institutions, surveillance, financial capitalism and sustained irresponsible economic growth reliant on predatory practices such as gentrification and the state's involvement in public scandals.

David Simon's The Wire has been signalled as representative of this phenomenon. For Xavier Antich, The Wire diagnoses the social failure of the capitalist system. What in 2008 showed the realities of a poor town in the US, today represents where we are" (2011: n. p.): For many, this could be summarized as a global apparatus in which financial capitalism has purchased enough public power to block significant social transformations. Analysing the series, Žižek revises how recent cultural critique against capitalist culture is based on practices of resistance against the market's aggressiveness, although he identifies in the series instances of utopia and points at examples of radical honesty in the story (2012: 97). Nonetheless, the show ultimately fails, as he argues, to transcend the limits of social realism and, this way, it does not present the abstract motions of capitalism, for which an entirely - perhaps a more Brechtian or Chapliniesque different turn would have served (Žižek 2012). The only choice left for individuals seems, as Žižek continues, to be patient resistance to the inevitable workings of the state apparatus and the 
The geopolitical context of the series. immerse in global conflict, terrorism. a lack of faith in the institutions particularly the Presidency of the US - and, importantly, the risk of socioeconomic exclusion affecting the US and the world's working classes should, in principle, make us think of complex TV works as politically concerned and progressive in their criticism of leading institutions, surveillance, financial capitalism and sustained irresponsible economic growth reliant on predatory practices such as gentrification and the state's involvement in public scandals. 
aggressiveness of financial capitalism (2012). Against this, Žižek proposes stopping all resistance to the dominant dispositif (2012), for acts of resistance only "keep the system alive" (2012: 109). Žižek's conclusion on the series is that: "Whatever the outcome, one thing is clear: only when we fully embrace Simon's tragic pessimism, accepting that there is no future (within the system), can an opening emerge for a radical change to come" (2012: 111).

In more positive terms, Hannah Wolfe Eisner traumatic redemption as a narrative experience which, fundamentally, does not dodge the ethical question of analysing the nature of pain. She defines trauma as an event which suddenly rips "its victims out of their lifeworlds." Trauma is "so sudden and violent that it cannot be fully processed in the moment," but it is remembered "in fragments through a mixture of disembodied and highly visceral sensations" (3). For Eisner, trauma and redemption should be studied within a relational rather than a linear framework. It does not presuppose a reconstitution of stability and order after disorder and instability (Eisner10-11). Instead, Eisner's non-linear angle favours close analysis of trauma in its concrete expressions. Her appropriation of Bakhtin's chronotope theory allows the arrangement of trauma-redemption experience in terms allowing their study. Rather than straightforward attention to healing, Eisner's model proposes to first take the effects of trauma seriously, exposing trauma's multiplicity and making of disorder part and parcel of the narrative.

For that purpose, she provides two sets of variables which can, as I will show, be used to explore redemption in complex TV series. Eisner differentiates "space-time" and "time-space" variables. The former denotes the material in which one's body and the rest of the universe exist. The latter denotes a world system in which narrative comes into play.The former applies to material

\section{Rather than straightforward attention to healing. Eisner's model proposes to first take the effects of trauma seriously, exposing trauma's multiplicity and making of disorder part and parcel of the} narrative.

reality, the latter to epistemology and ideology - or even teleology. These two inform about the range of nuanced interpretive possibilities within traumatic redemption. Crucially, time-spaces translate as conversations about trauma allowing individuals to develop different perceptions, memories and interpretations on their experiences and, also, to discern how these interpretations affect social interactions and social organizations (Eisner). Trauma is, thus, experienced differently by individuals and characters. Consequently, characters' individual redemptions take idiosyncratic forms.

Eisner inherits an additional set of variables from Theodore Adorno's essay "Commitment" from the New Left Review. On the aesthetics of sacrifice and suffering, Adorno claims that "The aesthetic principle of stylization, and even the solemn prayer of the chorus, make an unthinkable 
fate appear to have had some meaning; it is transfigured, something of its horror is removed. This alone does an injustice to the victims" (85). Eisner defines Adorno's term "transfiguration" by relating it to the transformation in an external appearance glorifying a given process. Seen from this angle, suffering and pain are elevated and sorrow serves a high purpose. Clearly, this is a narrative that many post-colonialist, feminist and classical Marxist scholars, artists and writers may challenge. Eisner also uses Lawrence Langer's concept of "disfiguration," i.e. the conscious and deliberate alienation of the reader's sensibilities from the world of the usual and familiar disorienting her/ him and, arguably, eliminating the possibility of aesthetic pleasure ${ }^{3}$. These two variables allow us to think of imaginative ways of representing the unrepresentable specificities of trauma. At the same time, they allow us, following Eisner's suggestions, to reconcile these representations with forms of narrative that represent ultimate forms of healing.

\section{THEORETICAL MODEL: CHRONOTOPE OF TRAUMATIC METHODOLOGICAL APPLICATION: ROME AND JULIUS CAESAR}

Both sets of variables can be used, as I intend to show, to describe the characters of Titus

\section{...two variables allow us to think of imaginative ways of representing the unrepresentable specificities of trauma. At the same time, they allow us, following Eisner's suggestions, to reconcile these representations with forms of narrative that represent ultimate forms of healing}

Pullo and Lucius Vorenus in Rome (BBC/HBO 2005-2007), written by Bruno Heller, John Milius and William J. MacDonald. The characters are based on two real centurions described by Gaius Julius Caesar in De Bello Gallicum. In Rome, they represent two differentiated ideological types despite their soldierly status and, as the series' progress shows, such ideological inclinations are determined by class. Naturally, their views on progress and redemption differ. Pullo, the son of a slave, is a simple soldier and Vorenus, coming from a wealthier but still non-aristocratic family, is a centurion

${ }^{3}$ See The Holocaust and the Literary Imagination. New Haven: Yale University Press, 1975. 
who quickly becomes prefect of the evocatti, later a senator, later captain of the Aventine Collegium. Their characters might well serve to embody the two ideologies that Shakespeare presents in the first act of Julius Caesar when the Cobbler and the two tribunes confront each other over Caesar's triumph. For the tribunes Flavius and Murellus, the Cobbler and the other citizens should rather be at work whereas the Cobbler and the crowd would rather celebrate Caesar's triumph. Similarly, competing worldviews regarding public responsibility are embodied in the protagonists of Rome. In Vorenus' case, a hard-working ethos based on loyalty to duty and to the principles laid down by the founding fathers at the Twelve Tables of the Roman Republic prevail over Julius Caesar's act of rebellion against the Republic. In Pullo's view, such acts of defiance are justified on the grounds of pure desire, buddy-boy camaraderie and the seemingly unstoppable power logic of testosterone. Pullo himself explains his worldview in the first episode: "I like to kill my enemies, take their gold, enjoy their women. That's it”. Rather than the emulation dynamics which define their rivalry in Caesar's account of the Gallic Wars, these two characters' conflict has to do with class and education. Most of their mutual attacks, scorns, fights and struggles amplify the taunting and bantering going on between the respectable tribunes, deeply devoted to the state and to the discipline required by office's dignity, and the scallywags who rejoice in Caesar's trampling over their brethren's corpses in Shakespeare. Oftentimes, Vorenus admonishes Pullo for being unreasonable, imbalanced, disobedient and unnecessarily violent. Pullo resents Vorenus' self-importance, his coldness, and, especially, his rapid promotion. Not accidentally, scene one in the series commences with a fisticuff exchange between Pullo and Vorenus in the middle of a skirmish with the Gauls after Pullo disobeys Vorenus' order to be back into the line.Vorenus' interpellation to Pullo echoes Murellus' command to the Plebeians:

\author{
Be gone! \\ Run to your houses, fall upon your knees, \\ Pray to the gods to intermit the plague \\ That needs must light on this ingratitude.(1.1.53-56)
}

Contrarily to what happens in Shakespeare's plays -in which the mob irrationally kills Cinna the Poet-, Rome allows the People of Rome moments to be at peace with themselves. As the series progresses, Pullo and Vorenus' bonds of friendship and brotherhood acquire more and more depth. If there is anything that Pullo and Vorenus' friendship symbolizes is the emancipatory possibility of union of peoples belonging to different social ranks in order to oppose or, at least, contend against the ideological, coercive and military forces that the state displays over the population.

Yet, such redemptive story is filled with dark stretches. Despite the simplicity with which he presents himself, Pullo's deep pain -much of which he recurrently recalls via storytelling about his parents- have hardened him and made him ready for dangerous situations. He only realises that something is going wrong with his own world when he decides to marry. Unconsciously, his own courage leads him away from the means to carry a genuinely happy existence in the terms he later pursues. For, despite their clear similarities in soldierly value, Vorenus quickly ascends through the political ladder and he does not. Pullo's plight is not unlike that of many US citizens belonging to depressed areas who, until the industry fell and the current financial crisis started, thought there would be always time to find the way to settle down. While some of them were hard-working, lucky, or clever enough to move up the social ladder, others did not have access to the means to do so. 
Pullo's suffering during the last episodes of series one develops through the steps in the process of ideological obfuscation identified by Žižek, whose borrowing of Elisabeth's KliiberRoss's classification may be of help here. Firstly, "denial" defines the individual's perception (2010: xii). "Anger" follows this first stage, which, in Pullo's case, is burdened by his awareness of his disadvantaged educational position. While Vorenus' parents raised horses in Mutina, Pullo, the son of a slave, has known no other trade except violence.

The radicalization of Rome's exploration of the Plebeians in Shakespeare's tragedy lies in its engagement with social, ideological and cultural divisions outside the Senate and the aristocracy. When Pullo is about to ask Eirene the slave's hand in marriage, he discovers that she is already engaged with another slave in Vorenus' house. Social difference reveals itself even there, for Pullo lacks the means to raise a family even with a slave. He belongs neither in communities of racialized freed people nor in the Roman elite. After killing Eirene's fiancé and being expelled from Vorenus' house, he engages in criminal activity and is arrested by the authorities. In the face of death, he undergoes the last stage Žižek points at. Disinterested in defending himself in trial or in fighting for his life, he develops "acceptance," which, for the Marxist philosopher, allows the subject to discern "the signs of an emerging emancipatory subjectivity" (2010: xii). Once he stops fighting against his own apparent doom as an outcast veteran without a future, he manages to win Eirene's forgiveness and her hand in marriage. As Monica S. Cyrino says, while Vorenus' downfall occurs in the last episode of season one,"Pullo is redeemed by his indissoluble bond with Vorenus and his own powerful instinct to survive. Even as Rome falls into turmoil with the assassination of Caesar, the final shot of Pullo walking hand-in-hand with his beloved Eirene, whose name means, "Peace," offers a visual promise of the ultimate survival of the Roman people" (6).

Pullo's redemption is not linear, for more violent episodes involving his wife will follow. Yet, I would like to focus on Vorenus' attempt to redeem himself from doom over season two. This intent is recognized by other characters who describe what he expects from his children once he calms after realising that his jealous rage has provoked the death of his wife Niobe.A solid, practical, hard-working man, his instincts dictate him when honour determines the course of action to follow and when it is best to look to the other side. For instance, though in episode 1 he commands Pullo to respect army protocols in battle, when Mark Antony sexually assaults a shepherdess en route to Rome, he justifies his general's act by saying that, while doing it, he is not under the thirteenth legion's standard. Aware of this microphysics of power necessary to survive in Rome, he thinks of his own and his family's prosperities as a matter of career progress, movement upward in the social scale and political promotion. Such forward-looking principle, which deliberately obscures details, is the one he intends to stick to in order to sort out the self-inflicted pain produced by the death of his wife Niobe. Being informed that Niobe conceived a child with another man when he was at war, Vorenus abandons Caesar, runs into his house and, threateningly approaches his terrified wife, who puts an end to her life by jumping from the verandah. His strategy, during season two, consists of obtaining his children's and his gods' forgiveness as soon as possible. When he rescues the children from slave camp (episode 2,4), he faces young Lucius, Niobe's son, momentarily. Instead of killing him, as honor dictates following the family's institutional patriarchal rules, he embraces the boy. From the corner of the room, Vorena, his daughter, who has been turned into a prostitute, observes 


\section{REDEN}

his father's reactions. Behind her back, a sinister doll hanging on the background produces a disturbing feeling revealing that everything will not be well. In fact, we know subsequently that Vorena and the kids plan to escape from their father as soon as possible. One shot presenting the reconciliation of Vorenus with his child seems to suggest that Niobe's sacrifice was meaningful whereas the disfiguration image of the doll as a marker for future turmoil unravels the optimistic resolution of this progressive affirmative narrative that Vorenus wants this event to be. The conclusion of Rome is just as problematic as the conclusion of Shakespeare's Winter's Tale. In Shakespeare's romance, Hermione's apparent resurrection seemingly crowns Leontes' longed-for redemption, though Hermione's silence in the final scene renders this conclusion suspicious. In

\section{One shot presenting the reconciliation of Vorenus with his child seems to suggest that Niobe's sacrifice was meaningful whereas the disfiguration image of the doll as a marker for future turmoil unravels the optimistic resolution of this progressive affirmative narrative that Vorenus wants this event to be.}

Rome, the last shot showing Vorena and her dying father in bed is brusquely cut. Thus, we are deprived of definitive conclusions regarding Vorena and Vorenus' reconciliation.

\section{JULIUS CAESAR BEYOND ROME}

Complex TV series have had an impact in contemporary Shakespearean performance ${ }^{4}$. A comparative approach to read a corpus of Shakespearean adaptations from the lens of traumatic redemption - and, interestingly, following Douglas Lanier's rhizomatic model, using Rome as vantage point - permits examining a selection of adaptations of Julius Caesaras trauma-redemption dialectics. As Lanier suggests, the corpus of Shakespearean adaptations, sources, afterlifes and scripts do not need to be presented in a hierarchical or chronological order. A dialogue rooted in historical specificity involving all adaptations as well as the original text allows inquiry into the concerns present in Rome as these are transferred to other adaptations of Julius Caesar. This way, cultural meanings mobilized in Rome may be vantage points to study other adaptations.

For instance, the study of Rome from this angle would require an engagement with materialist and historicist criticism on the role of the Plebeians in Shakespeare's Roman plays. My analyses should address the question of whether Bruno Heller's show responds to past or current

${ }^{4}$ Sophie Bourdais mentions a few productions from the 2014 Avignon Festival in which the duration of Henry VI, redesigned by Thomas Jolly and La Piccola Familia company, took the shape of two seasons imitating the TV serial format with cliff-hangers and 'rhapsods' summarizing preceding episodes. Other collaborations have taken place between artists of Shakespeare-inflected series and theatre artists. Stage productions of Hamlet have been mounted using the 


\section{concerns in the representation of the People in Julius Caesar.}

Rome clearly responds to these concerns ambivalently. For, contrarily to what cultural materialist and to what conservative critics have respectively promoted, it refuses, for better or for worse, to simplify the People of Rome. Instead, it displays the whole social map of Rome with all its complexities, its shadows and its lights. It makes the socio-economic differences between centurions and soldiers evident through Pullo and Vorenus' often conflictive friendship. It displays the relations of rivalry and solidarity between women in the series -through the evolving journeys of Atia of the Julii and her daughter Octavia-. Likewise, it stresses the political importance of women in the Roman politics which Shakespeare leaves unattended. It largely represents the ethnic and racial prejudices in the Roman society but, also, it reveals the survival strategies of some of the characters heavily marked by alterity. For instance, the Greek slave Posca at times seemingly emulates Lear's Fool, for he is one of the few characters -together with Antony and Octavianwho speak their true minds in front of Caesar. Timon, a Jewish tradesman and an assassin, trying to pass himself as a businessman - perhaps alluding to Shakespeare's hero in Timon of Athensexperiences his own redemption journey via sexual involvement and affiliation with a high-class woman, Atia of the Julii, who hires him to carry out criminal acts. Resentful with his domina, Timon joins a radical group intending to overthrow Roman rule in Israel. Yet, when he has the chance to assassinate King Herod in his visit to Rome, seeing that Atia travels near the Eastern monarch, he chooses to abandon this enterprise, go back to his family and leave Rome for good. As the Roman aristocracy, the Roman plebs are embedded in the power dynamics of Rome, which becomes a

aesthetics of Six Feet Under and 24 Hours (2014).Jonathan Stamp, historical assessor for Rome, took part in the writing of the programme for Lucy Bailey's RSC production of Julius Caesar in 2009, for which she borrowed the color palette of the series.Also, as she says, she found the show astonishingly fresh and tapped into the addictive violence and brutality that I found in the play' (2009). Comments have been made on how the appearance of actors from complex TV series may affect our interpretations of their partaking in contemporary Shakespearean productions. Thus, as Erin Weinberg says, taking into account his role in GOT, we could read Robert Pugh's interpretation of Glendower in Richard Eyre's Henry IV Part 1 from the lens of GOT. This way, Pugh's Glendower, influenced by Craster, a character who commands the spirits lying beyond the wall in HBO's epic fantasy, may be read not as a caricature of a magician as Harry Hotspur does but in rather darker and more serious ways (2014). Local and amateur productions of Shakespearean plays have been part of this phenomenon too. We have news of a High School play, Game of Tiaras, written by Don Zolidis, adapting King Lear with the heritage of Disney and GOT in mind. In 2016, the University of Nebraska and Omaha partnered with Creighton University and Nebraska Shakespeare to mount of a production of The Wars of the Roses keeping the popular impact of GOT in mind. More straightforwardly, in April 2016, a troupe of 36 sixteen- to nineteen-year-old actors mounted a production of The Wars of the Roses at Warwick called Games and Thrones. Parallels with HBO's work went beyond the cast's youth and the title. As James Rodgers says, Playbox's production wanted to 'fully immerse the audience in the story - which house [would] they support, the red or white rose? Which contender to the throne [would get] their vote? Which acts of treachery and plotting [would] they condone or condemn?' (2016). With this practice, immersive theatre imitated some of the strategies of engagement of complex TV based on the creation of blogs, forums and social networks rallying viewers to speculate, opine and intervene in the narrative. Crucially, this would imitate HBO's practice of transforming audiences into potential judges of characters, as has been the case with the series. An additional example is the Henry VI presented by Phil Willmott Company: HVI: A Play of Thrones, adapted from Shakespeare's plays by Willmott himself an explicitly marketed as 'The brutal reality that inspired RR Martin's novels' and as 'A passionate accessible take on Shakespeare'. Nonetheless, these GOT-based initiatives on stage may fall flat. Icarus Theatre Company makes a point to perform Shakespeares for the HBO generation and to embrace HBO's fantasist conceits. 
character in its own right. Thus, rather than choosing to favor any of the two meta-narratives - progressive and skeptic- on the Roman Plebs, HBO embraces a dialectical view and places the People's complexities, virtues and inclinations to irrational violence center-stage.

The recent films Cesare Deve Morire (Taviani Brothers, 2012) and Julius Caesar (Phyllida Lloyd, 2018), both framed within the genre of Prison Shakespeares, are, like Rome, people-centered Shakespearean adaptations in which male and female convicts use theatre and Shakespeare's tragedy to explore their own traumatic experiences. While the Taviani's film stresses the healing, curative and emancipatory potentialities of literature, drama and Shakespeare's words for a group of fairly enlightened prisoners at the institutional penitentiary of Rebbibbia (Rome), the female cast of actresses in Lloyd's film interpret the characters as male, thus engaged with the Brechtian fashion of depicting the brutal, de-humanized and stark macho politics of prison using estrangement mechanisms that disallow affirmative conclusions for the self-proclaimed curative quest the female prisoners seek in doing the play. The realistic documentary style followed by the Tavianis reinforces a redemptive prison narrative in which, after meeting Shakespeare, some prisoners make sense of their life and find ways out of darkness through literature and drama. The Brechtian style in Lloyd's film displays metatheatrical strategies which, by pointing at the performance, depict the details of arbitrary violence in ways that echo the abuse that these female convicts must have suffered. Suffering becomes meaningless, obsessive, not a means to achieve a higher end, but a constant struggle to negotiate the dialectics of hope and suffering.

At a time in which, following Žižek, "the global capitalist system is approaching its apocalyptic zero point" (2010: x), a focus on social division, inequality, rage, suffering, trauma and search for forms of enlightenment seem a fitting choice for appropriations of Julius Caesar. These two films radically engage with the popular zeitgeist of Rome in order to explore class, education and masculinity issues and, also, to exercise the intellectually and theatrically compelling exercise of having women play male characters in ways that depict, show and expose -rather than encourage identification with- the male characters in the play.

\section{CONCLUSIONS}

This essay has shown that, to a great extent, the Shakespearean intertext contributes to add layers of meaning to current redemption narratives. Since trauma culture affects varied geographies and localities, particularly those affected by social division - particularly, regarding gender and ethnicity-, economic hardship and identity crisis, Eisner's theory allows us to think of complex TV series as lenses to look into worldwide Shakespearean adaptations and appropriations.

Furthermore, this may be possible even with complex TV serials whose relations with Shakespeare have been proved only in sketchy ways. Jo Nesbø's Macbeth is, resembling the Norwegian author's Harry Hole series, inserted in the grey urban landscapes subsumed in wild late capitalism, political corruption and drug-dealing. Characters are ridden by guilt-atonement and a constant need to make up their minds in the face of a world where honesty inside institutions seems suicidal, especially for working-class types, whose choices are limited by the operating mechanisms of social inequality and educational difference. This novel lends itself to comparison 
with the serial format developed by complex TV. Particularly, it lends itself to a reading alongside The Wire, for it addresses concerns and questions which Simon tackles. Additionally, it is also worth reading The Wire in contrast with Michael Almereyda's film adaptation of Cymbeline (2014). Arguably, the setting chosen for this adaptation -a US city in which a gang of drug-dealers (the Britons) constantly fight with the police (the Romans) - might be proposed as a utopian alternative to the insufficient progressive politics of The Wire, for conventions of Shakespearean romance indeed, contrarily to The Wire, transcend the parameters of social realism. At the same time, The Wire and the conventions it develops provide a solid set of guidelines to study the transformations and variations of the conventions of Shakespearean romance embedded in the world depicted by the series. Potentially, Shakespearean romance provides ways out in a chronotope in which Simon's politics falls short.

Reading serial Shakespeares from the lens of traumatic redemption maps the way in which Shakespearean reception evolves across the centuries, for series often draw ideas from Shakespearean reception and performance histories. Observing, for instance, the character of Claire Underwood from House of Cards (David Fincher, 2012-2018) in the light of the US's overall interpretation of the Scottish heroine Lady Macbeth in performance, it is observed that the physical and magnetic character played by Robin Wright departs from and radically transforms standing misogynistic representations of Lady Macbeth: a powerful female who, nonetheless, shows too many signs of instability to leave government in her hands. Needless to say, such myth has been used in order to disqualify the potential as leaders of First Ladies such as Hillary Clinton and previous US female political leaders. Claire's characterization seems to run along other characterizations of the Shakespearean heroine which, in the early twenty-first century, have re-considered Lady Macbeth' agency. Sarah Fraser King's protagonist in Lady Macbeth is solid, resourceful and capable of military prowess - as this historical novel suggests. Nonetheless, ultimately, her subordinate role is confirmed despite the amount of equality granted to the couple in Fraser King's exploration. Melanie Karsak's four-part saga Celtic Blood more radically re-reads Lady Macbeth as a queenin-the-making who is not only decided to rule but who is also decided to be a mother of many children and, while revengeful, is also capable, thanks to her magical powers and her romantic relationship with Banquo of Lochaber, to create, envisage and inhabit alternative worlds outside the hetero-normative, war-ridden and male-centered kingdom of Scotland.

Reading Shakespearean adaptations and appropriations across geographies and transcending genre-specific -and, as Lloyd's film shows, gender-specific- barriers, we find that serial Shakespeares are barometers of the shape Shakespearean performance seems to be taking in the global landscape. They do so not just at surface level -via the odd casting of an HBO actor in a Shakespearean production, for instance, though this is a frequent strategy- but with regard to their attention to deeper intertextual, political, ideological and cultural meanings calling for crossmedia analyses. 


\section{References}

Macmillan, 2002. Print.

Anderson, C. "Producing an Aristocracy of Culture in American Television". The Essential HBO Reader. G.R.Edgerton \& Jones. Eds.Lexington, Kentucky: The University of Kentucky Press, 2008: 28-41. Print.

Antich,X. “Momento 'The Wire'. La Vanguardia. 19 September 2011. Web.

Bailey, L."Field of Blood (Director Lucy Bailey Discusses Some of the Inspiration Behind HerVision of the Play".Programme for LucyBailey's production of Shakespeare's Julius Caesar. Royal Shakespeare Company, 2009.

Bataille,S. "Haunted by Shakespeare: HBO's Rome”. Television Shakespeare: Essays in Honour of Michèle Willems. S. Hatchuel \& N. Vienne-Guerrin. Eds.

Mont-Saint-Aignan Cedex: Publications des Universités de Rouen et du Havre, 2008 : 219-249. Print.

--.. “How Many Times Shall Caesar Bleed in Sport”: Recent 'Roman' TV Productions and the Shakespeare Legacy". Shakespeare on Screen: The Roman Plays. S. Hatchuel \& N. Vienne-Guerrin. Eds. Mont-Saint-Aignan Cedex: Publications des Universités de Rouen et du Havre, 2009: 225-237. Print.

---.'Hamlet on Harleys': Sons of Anarchy's Appropriation of Hamlet”. Shakespeare on Screen: Hamlet. S. Hatchuel \& N. Vienne-Guerrin. Eds. Mont-Saint Aignan Cedex : Publications des Universités de Rouen et du Havre, 2011: 329-344. Print.

Bennett, S. "Shakespeare's New Marketplace: The Places of Event Cinema". Shakespeare and the 'Live' Broadcast Experience. P. Aebischer, S. Greenhalgh \& L. E. Osborne. London and New York: The Arden Shakespeare, Bloomsbury Publishing Plc, 2018: 41-58. Print.

Bourdais, S. "Entre Shakespeare et les séries, c'est Game of clones". Télérama (Séries TV). 2014. Web.

Bristol, M. D. Big-Time Shakespeare, London and New York: Routledge, 1996. Print. Burzynska, K."Bad Boys Meet the Swan of Avon: A Re-Visioning of Hamlet in Sons of Anarchy”. Studia Anglica Posnaniensia 52:2.2017. Web.

Cascajosa-Virino, C. La Cultura de las Series. Barcelona: Laertes SL Ediciones, [2015] 2016. Print.

Ceballos, N. “'Westworld': Por Fin una Serie Sobre Cómo se Hace una Serie". Revista GQ.2016. Web.

Cyrino, M. S. "Introduction". Rome Season One: History Makes Television. M. S. Cyrino. Ed. Oxford and Victoria (Australia): Blackwell Publishing, 2008: 1-10.

Eisner, H. W. Into the Middle of Things: Traumatic Redemption and the Politics of Form. Thesis. Connecticut: Wesleyan University. 2017. Web.

Földváry,K."Serial Shakespeare: The Case of Star-Crossed (2014)". Forme,Strategie e Mutazioni del Racconto Seriale. Between 7: 11.2016. Web. 
Ford, R. 'Sons of Anarchy' Showrunner Kurt Sutter on the 'Heartbreaking' Finale (Q\&A)". The Hollywood Reporter. 2013. Web.

Jackson, R. “Salus Populi: Shakespeare's Roman Plebeians on Screen”. Shakespeare on Screen: The Roman Plays. S. Hatchuel \& N. Vienne-Guerrin. Eds. Mont-Saint-Aignan Cedex: Publications des Universités de Rouen et du Havre, 2009: 143-176. Print.

Koon, H.W. How Shakespeare Won the West (Players and Performances in America's Gold Rush, 1849-1865). Jefferson, North Carolina; London: McFarland \& Company Inc. Publishers, 1989. Print.

Lanier, D. "Shakespearean Rhizomatics: Adaptation, Ethics, Value". Shakespeare and the Ethics of Appropriation. E. Rivlin \& A. Huang. Eds. New York: Palgrave Macmillan, 2014: 21-40. Print.

Mittel, J. Complex TV (The Poetics of Contemporary Television Storytelling). New York: New York University Press, 2015. Print.

Patches, M. "Remember the 'Westworld' Finale's Violent End Before the Season 2 Premiere". Thrillist. 2018. Web.

Pollack-Pelzner, D. "Westworld Is Full of Shakespeare Quotations, but It's Using Them All Wrong”. Slate. 2016. Web.

Robinson, J."Sons of Anarchy Series Finale Rides Off Into the Sunset on a WornOut Metaphor". Vanity Fair. December 2014. Web.

Rodemerk, D. "Here Are All the Shakespeare Quotes Found in Westworld". Winteriscoming. 14 January 2018. Web.

Rodgers, J. "Games of Thrones comes to Warwick to mark Shakespeare's death". Coventry Telegraph. 2016. Web.

Ronnenberg, S. C. Deadwood and Shakespeare (The Henriad in the Old West Jefferson: McFarland \& Company Inc. Publishers, 2018. Print.

Saporito, J. "When exactly is winter coming in "Game of Thrones"? What does that even mean?" ScreenPrism. 2015. Web.

Shakespeare, W. Julius Caesar. D. Daniell. Ed. London; New York: Bloomsbury Publishings, Plc, [1623]1998. Print.

Smith, T. L. "'Sons of Anarchy': The Lasting Legacy of FX's Groundbreaking Biker Drama”. Cleveland. December 2014. Web.

Tracey, J. "In HBO's Westworld, Literature Is the Key to Personhood". Ploughshares .2019. Web.

Walsh, K. "What Shakespeare Play Is The "Violent Delights" Quote From On “Westworld'? It's Popular”. Romper. 23 October 2016. Web.

Weinberg, E. "Creative casting: Shakespeare featuring Game of Thrones actors". The Bardolator. 24 October 2014. Web.

Žižek, S. Living in the End Times. London; New York: Verso, 2010. Print.

--- The Year of Dreaming Dangerously. London; New York: Verso, 2012.Print.

--.."Game of Thrones tapped into fears of revolution and political women - and left us no better off than before". Independent. 2019. Web. 